\section{Bioética política na desconstrução do SUS}

Costa, Tânia Mara Borges da

Doutoranda e Membro do Grupo de Estudos, Pesquisa e Extensão em Políticas Públicas, Direito à saúde e BioéticaBIOGEPE. da Faculdade de Direito de Vitória (FDV). Email:tborgesdacosta@gmail.com

\section{Bussiguer, Elda Coelho de Azevedo}

Livre Docente pela Universidade do Rio de Janeiro UniRio. Doutora em Bioética pela Universidade de Brasília - UnB. Mestre em Direitos e Garantias Fundamentais pela Faculdade de Direito de Vitória - FDV. Coordenadora do Programa de Pós-Graduação em Direito da Faculdade de Direito de Vitória - FDV. Editora da Revista Direitos e Garantias Fundamentais (QUALIS A 1). Coordenadora do Grupo do BIOGEPE - Grupo de Estudos, Pesquisa e Extensão em Políticas Públicas, Direito à saúde e Bioética. Membro do Conselho científico da Sociedade Brasileira de Bioética.

PALAVRAS-CHAVE: SUS: PEC 241/16; saúde; bioética política.

INTRODUÇÃO: No congelamento dos recursos da Saúde por 20 anos (PEC 241/2016 e 55/2017), com Rossi e Dweck ((2016), observa-se que os recursos já eram reduzidos pela Emenda Constitucional 86/15, sob percentual escalonado da Receita Corrente Líquida (RCL) com: 13,2\% em 2016; $13,7 \%$ em 2017; 14,2\% em 2018; 14,7\% em 2019 e $15 \%$ a partir de 2020. Com a PEC 55/2017 o gasto será $15 \%$ da RCL. A partir de então, como piso mínimo, deslizante, caindo em proporção das receitas e do PIB. Previsto $12 \%$ da RCL em 2026 e 9,4\% em 2036. Neste sentido, o objetivo aqui é refletir sobre os reflexos deste congelamento na desconstrução do SUS, sob o método dialético qualitativo e documental. Os resultados evidenciam inobservância aos Objetivos e aos Direitos e Garantias Fundamentais constitucionais, aumento da desigualdade, política regulatória ilegítima e excludente. Possibilitando aos Poderes se acobertarem sob o manto procedimental da Reserva Legal, para afastar o Estado da tutela obrigacional e da responsabilização pela materialização efetiva da Saúde. Condutas dissociadas da Bioética, da ética pública para a vida. Que vistas com Fabriz e Paula, legitimam-se pelas exceções constitucionais e tornam-se regras para as políticas globalizadas de governos democráticos, promovem enriquecimento de uma minoria e maior empobrecimento das nações. Visão abordada ainda, por Adeodato (1989) em sua análise sobre a ética e o problema da legitimidade e legitimação para os países subdesenvolvidos. Questões de natureza éticas-jurídicas, também analisadas por Krohling, Pereira \& Pereira, quanto ao imperioso repensar as responsabilidades, diante das novas perspectivas da Bioética e do Biodireito, que se impõem sobre a gestão da Saúde. As quais não podem estar dissociadas da necessidade por fundamentações racionais em relação às questões das fragilidades da Bioética e do Direito, fato que Bussinguer (2016) vislumbra em ambas, enquanto áreas do saber, potencialidades que cada uma delas leva para o diálogo e para a construção de uma relação virtuosa, em busca de uma finalidade comum, tendo em vista o alcance de uma justiça justa que considere a incorporação de valores como condição indispensável à efetivação dos Direitos Fundamentais. Conclui-se ser indefensável uma tese antiética, na qual o cidadão pode existir indignamente, sem efetividade da Saúde. E, pela necessária salvaguarda contra a desconstrução do SUS, sob risco do bem-estar social e do Estado Democrático de Direito. Pela integração e inteiração de políticas em prol dos movimentos sociais, das Audiências, dos Conselhos e das Políticas Públicas da Saúde. Sob a égide da Bioética e do Biodireito, com participação social e transparência democrática, na busca de Reformas e Emendas Constitucionais que promovam a manutenção do SUS sob descentralização, atendimento integral e universal, visando uma sociedade justa e solidária, garantindo o desenvolvimento sustentável. Pois, Saúde é Direito Fundamental e dever do Estado, mediante políticas sociais e econômicas que visem à redução do risco de doença e de outros agravos e ao acesso universal e igualitário às ações e serviços para sua promoção, proteção e recuperação, visando com base no primado do trabalho, a ordem social, o bemestar e a justiça sociais.

\section{REFERÊNCIAS}

[1] ADEODATO, João Maurício Leitão. O problema da legitimidade: no rastro do pensamento de Hannah Arendt. Forense Universitária, 1989.

[2] BUSSINGUER, Elda Coelho de Azevedo. A teoria da proporcionalidade de Robert Alexy: uma contribuição epistêmica para a construção de uma bioética latinoamericana. 2016.

[3] FABRIZ, Daury Cesar; PAULA, Rodrigo Francisco de. A Constituição em Tempos Sombrios: quando a exceção vira regra de governo na democracia. In: O tempo e os direitos humanos. (Org)

[4] KROHLING, Aloísio; KROHLING, Beatriz Stella Martins. Ética rizomática e teoria crítica do direito internacional dos direitos humanos. Revista de Estudos Constitucionais, Hermenêutica e Teoria do Direito, v. 5, n. 1, p. 82-92, 2013.

[5] ROSSI, Pedro; DWECK, Esther. Impactos do novo regime fiscal na saúde e educação. Cadernos de Saúde Pública, v. 32, p. e00194316, 2016. 